\title{
MENGEMBANGKAN KEMAMPUAN MENGENAL ANGKA 1-10 MELALUI KARTU ANGKA PADA TAMAN KANAK KANAK KELOMPOK A
}

\author{
Isabella Hasiana $^{1}$, Aniek Wirastania ${ }^{2}$ \\ ${ }^{1}$ Pendidikan Guru - Pendidikan Anak Usia Dini Fakultas Keguruan dan Ilmu Pendidikan Universitas PGRI Adi \\ Buana Surabaya \\ ${ }^{2}$ Bimbingan dan Konseling, Fakultas Keguruan dan Ilmu Pendidikan, Universitas PGRI Adi Buana Surabaya \\ Email : icha1916@yahoo.co.id, daniek.bk04@gmail.com
}

\begin{abstract}
Early childhood development is important and needs to be developed especially in education. One aspect that needs to be developed in early childhood education is the ability to recognize the concept of numbers. Therefore, it takes a strategy in learning to introduce the concept of numbers. This study aims to develop students ability in recognizing the concept of numbers 1-10 by using a number card. The type of research used is quasi experimental design (quasi experiment). The quasi experimental design used in this study is a non-equivalent pretest-posttest control group design. The results of this study were analyzed by the T test conducted using the help of SPSS program. Based on the results of research conducted obtained with sig $(0,000)<0.05$ which means there is a difference between the experimental group with the control group in recognizing the concept of numbers by using a number card. So it can be concluded that the number cards have an influence in improving the ability to recognize the numbers in children group A.
\end{abstract}

Keywords: Figures, Number Cards, Early Childhood

\section{PENDAhUluan}

Usia dini merupakan masa peka yang sangat penting bagi anak untuk mendapatkan pendidikan yang sesuai dengan usianya. Oleh karena itu, pengalaman yang didapatkan dari lingkungan sekitar termasuk dalam pemberian stimulasi yang diberikan kepada anak memiliki pengaruh besar bagi kehidupannya pada masa mendatang. Sehingga, sangat diperlukan upaya yang tepat dan sesuai agar pertumbuhan dan perkembangan anak dapat berlangsung secara optimal.

Salah satu cara untuk mengoptimalkan pertumbuhan dan perkembangan anak adalah dengan memberikan kegiatan pendidikan dan pembelajaran yang sesuai dengan usia, kebutuhan dan minat anak.

Pemberian rangsangan pendidikan kepada anak sejak usia dini merupakan waktu yang tepat untuk membimbing anak dalam proses pertumbuhan dan perkembangannya. Anak usia dini pada masa ini kemampuan otaknya memiliki daya serap tinggi yang didapatkan dari pengalaman-pengalaman sensorinya. Dengan kata lain, anak mudah belajar banyak hal dari lingkungan sekitar sehingga pada masa ini juga perlu dimanfaatkan dengan sebaik-baiknya agar seluruh potensi yang dimiliki anak dapat berkembang secara optimal.

Usia dini merupakan usia yang efektif untuk mengembangkan berbagai potensi yang dimiliki oleh anak. Upaya pengembangan ini dapat dilakukan melalui berbagai hal salah satunya dengan permainan dan media berhitung. Permainan berhitung yang ada di taman kanak-kanak tidak hanya terkait dengan kemampuan kognitif saja tetapi juga menyangkut kemampuan mental sosial dan emosional peserta didik. Oleh karena itu, dalam pelaksanaannya harus dilakukan secara menarik, bervariasi, dan menyenangkan (Depdiknas, 2007).

Anak usia dini pada usia 5-6 tahun sudah memiliki kemampuan mengenal angka 1-10 dengan menggunakan media benda yang konkret ataupun tanpa media. Menurut vygotsky, anak usia dini masih belum mampu untuk berpikir abstrak. Bagi anak, makna dan objek berbaur menjadi satu (Mayke, 2001). Anak masih memerlukan benda konkret untuk memahami sesuatu. Mengajarkan konsep angka pada anak tentu harus diawali dengan hal-hal yang ada di sekitar anak, misalnya anak menghitung jumlah pensil yang dibawanya, menghitung jumlah teman di 
kelasnya, dan menghitung jari tangannya. Untuk pembelajaran mengenal angka pada anak, tentu diperlukan proses yang berjalan secara perlahan-lahan tanpa paksaan, dan dilakukan dengan santai, menyenangkan serta sambil bermain (Hasan, 2009).

Dalam Permendiknas Nomor 58 Tahun 2010, dinyatakan anak usia 4-5 tahun atau Kelompok A sudah mampu untuk mengetahui konsep banyak sedikit, membilang banyak benda 1-10, mampu mengenal konsep bilangan, mengenal lambang bilangan, dan mengenal lambang huruf.

Dalam mengenalkan konsep bilangan, tentunya akan memerlukan pembelajaran yang menyenangkan agar anak tertarik untuk mengerjakannya. Untuk mengajarkan anak belajar berhitung, dapat melalui berbagai cara, antara lain (1) anak membilang melalui nyanyian, dengan jari anak, benda-benda, ataupun sambil berolahraga, (2) dapat dikenalkan bentuk angka 1-10 terlebih dahulu agar anak mengenal bentuk angka dari angkaangka yang sering diucapkan oleh anak, (3) anak diajak untuk mengurutkan angka yang sudah diacak oleh guru supaya diurutkan sesuai angka yang benar, (4) mengurutkan adalah memasangkan angka yang ada tersebut dengan bendanya, (5) tahapan yang terakhir dalam mengenalkan angka yaitu menuliskan angka sebagai lambang banyaknya benda (Fitriyanti, 2015).

Salah satu prinsip perkembangan anak usia dini adalah belajar melalui media. Penggunaan media yang sesuai untuk anak usia dini dalam pengenalan matematika memiliki peranan yang sangat besar. Manfaat penggunaan media dalam pengenalan matematika yaitu untuk membantu anak dalam memahami berbagai konsep matematika yang bersifat abstrak dapat disajikan dalam bentuk kongkrit sehingga mudah dimengerti dan dipahami oleh anak (Pujiastutik dan Setyowati, 2010).

Berdasarkan temuan pada observasi awal, ditemukan bahwa metode pembelajaran yang diterapkan sebatas metode tanya jawab dan pemberian tugas untuk menuliskan bentuk angkanya saja. Namun demikian, anak tidak mengerti makna dari angka yang ditulisnya tersebut.

Selain itu, penggunaan media yang kurang tepat, area pembelajaran yang terbatas, kurangnya alat peraga sebagai media, dan minat dan motivasi dalam belajar yang kurang juga membuat anak kurang tertarik untuk mengembangkan kemampuan mengenal konsep angka.

Materi pengenalan konsep bilangan pada anak usia dini, meliputi: membilang, menyebutkan urutan bilangan 1-10, membuat urutan bilangan 1-10 dengan benda-benda, menghubungkan dan memasangkan lambang bilangan dengan benda-benda 1-10 (anak tidak disuruh untuk menulis) (Asiyah dalam file:///C:/Users/user/Downloads/2527-4449-1SM.pdf).

Pada dasarnya, untuk mengenalkan konsep angka kepada anak usia dini diperlukan strategi yang cocok dengan masa anak-anak yaitu bermain. Hal ini dikarenakan dunia anak adalah dunia bermain. Oleh karena itu, dalam memberikan pembelajaran hendaknya juga dilakukan dengan bermain.

Bermain bagi anak usia dini memiliki arti yang penting karena dalam bermain anak akan terangsang kemampuan sosial emosinya, kognitifnya, bahasanya, nilai moral dan agama, serta fisik dan motorik sehingga anak menjadi lebih sehat dan tetap ingin bermain meskipun mengalami kelelahan (Jarwati, 2012).

Anak usia 3-5 tahun adalah masamasa permainan. Bermain dengan benda atau alat permainan dimulai sejak usia satu tahun pertama dalam kehidupannya dan akan mencapai puncaknya pada usia 5-6 tahun. Pada masa ini juga, anak akan lebih peka untuk berkembang. Oleh sebab itulah, mengapa pada masa ini dikatakan sebagai masa yang efektif bagi guru (pendidik) dan orang tua dalam memberikan pemahaman atau pembelajaran kepada anak melalui pemberian contoh-contoh konkret ataupun beberapa peragaan yang mendidik akan lebih mudah diterima secara efektif oleh anak (Asiyah dalam file:///C:/Users/user/Downloads/25274449-1-SM.pdf).

\section{KAJIAN LITERATUR \\ a. Pengertian Media}

Media pembelajaran adalah sarana pendidikan yang dapat digunakan sebagai perantara dalam mencapai tujuan pengajaran. Dalam pengertian yang lebih luas, dapat dikatakan bahwa media pembelajaran adalah alat, metode, dan teknik yang digunakan dalam kegiatan untuk lebih mengefektifkan komunikasi dan interaksi antara guru dan 
murid saat proses pembelajaran berlangsung (Sanaky, 2011).

Senada dengan hal tersebut di atas, dapat juga dikatakan bahwa media pembelajaran adalah segala sesuatu yang dapat dipakai atau dimanfaatkan untuk merangsang daya pikir, perasaan, perhatian dan kemampuan anak sehingga ia mampu mendorong terjadinya suatu proses belajar mengajar pada diri anak (Fitriyanti, 2015).

Media pembelajaran yang digunakan tentu memiliki manfaat, antara lain (1) menumbuhkan motivasi belajar pada anak, (2) Anak akan lebih jelas maknanya sehingga dapat lebih dipahami serta dapat menguasai tujuan pengajaran, (3) metode pembelajaran bervariasi dan tidak membosankan dan pengajar tidak kehabisan tenaga, (4) pembelajar atau murid akan lebih banyak melakukan kegiatan belajar dan tidak hanya mendengarkan penjelasan dari guru. Anak menjadi lebih aktif untuk mengamati, mendemonstrasikan dan mengekplorasi kan potensinya (Sanaky, 2011).

Media pembelajaran dapat memperjelas penyajian pesan dan informasi sehingga hal ini dapat memperlancar dan meningkatkan proses dan hasil belajar. Selain itu, media pembelajaran juga dapat meningkatkan dan mengarahkan perhatian anak sehingga dapat menimbulkan motivasi belajar dalam diri anak, adanya interaksi langsung antara anak dengan guru, masyarakat, lingkungannya serta dapat mengatasi keterbatasan indera, ruang, dan waktu.

Banyak hasil penelitian yang menunjukkan betapa pentingnya suatu media digunakan dalam proses pembelajaran. Salah satu media yang dapat digunakan dalam pembelajaran pengenalan konsep angka di TK yaitu dengan menggunakan media kartu angka.

\section{b. Pengertian Kartu Angka}

Kartu angka atau alat peraga kartu adalah alat-alat atau perlengkapan yang digunakan oleh seorang guru dalam mengajar yang berupa kartu dengan bertuliskan angka sesuai dengan tema yang diajarkan (http://jun212w.blogspot.co.id/2013/12/penelit ian-tindakan-kelas_17.html).

Menurut Tadkirotun (2012), kartu angka merupakan fasilitas yang penting dalam melakukan pembelajaran di sekolah karena sangat bermanfaat untuk meningkatkan perhatian anak. Dengan alat peraga kartu, anak diajak secara aktif untuk memperhatikan apa yang disampaikan oleh guru. Penggunaan media kartu angka ini sangat penting untuk menunjang proses pembelajaran pengenalan angka bagi anak usia dini.

Kartu angka juga merupakan suatu media pengajaran yang penyajiannya secara diagramatik dengan menggunakan lambanglambang visul, untuk mendapatkan informasi (Asnawir, 2002). Selain itu, ada pendapat lain yang juga mendefinisikan tentang kartu angka yang merupakan alat bantu paling penting untuk melatih dan memperkuat kemampuan mengenal bilangan, meningkatkan kemampuan menyebut sambil mengembangkan kemampuan mengenal bilangan (Tarjono, 2003).

Kartu angka yang dimaksud dalam penelitian ini adalah beberapa kartu yang terbuat dari kertas karton atau kertas manila, ukurannya kurang lebih 10x10 cm dan disetiap kartu tersebut tertulis satu lambang bilangan.

\section{c. Kemampuan Mengenal Angka 1-10}

Untuk kelompok usia 4-5 tahun, menurut Permendiknas 58 Tahun 2009 pengenalan bilangan ini meliputi membilang dan menunjuk benda (mengenal konsep bilangan dengan benda-benda) 1 sampai 10, menunjuk urutan benda untuk bilangan 1 sampai 10, membuat urutan bilangan 1 sampai 10, dan melakukan penjumlahan sederhana.

Anak dikatakan mengenal lambang bilangan dengan baik apabila dia tidak hanya sekedar menghafal lambang bilangan, namun telah mengenal bentuk dan makna dari bilangan tersebut dengan baik.

Bilangan dan angka merupakan dua hal yang berbeda. Bilangan mewakili banyaknya suatu benda. Simbol ataupun lambang yang digunakan untuk mewakili suatu bilangan disebut sebagai lambang bilangan atau angka. Angka adalah suatu lambang tertulis sebagai anggota dari suatu sistem penghitungan dan pengukuran (Fitriyanti, 2015).

\section{METODE PENELITIAN}

Metode penelitian yang digunakan dalam penelitian ini menggunakan pendekatan kuantitatif. Pendekatan ini merupakan pendekatan yang dilakukan guna mendapatkan gambaran secara empirik tingkat kemampuan 
anak-anak TK kelompok A dalam mengenal angka.

Metode yang digunakan dalam penelitian ini adalah quasi experimental design (eksperimen semu). Penggunaan metode quasi experimental design dilakukan agar dapat mencapai tujuan penelitian yaitu meningkatkan kemampuan mengenal angka 110 pada anak TK Kelompok A.

Desain quasi eksperimen yang digunakan dalam penelitian ini adalah nonequivalen pretest-posttest control group design (Sugiyono 2011) yang dilakukan dalam uji lapangan program bimbingan menggunakan media musik dalam meningkatkan kemampuan mengenal bilangan pada anak TK A Kelompok A. Gambaran alur pelaksanaan penelitian dapat dilihat dalam tabel dibawah ini.

\begin{tabular}{|c|c|c|c|}
\hline Kelompok & $\begin{array}{c}\text { Pre- } \\
\text { test }\end{array}$ & $\begin{array}{c}\text { Pelaksanaan } \\
\text { Program }\end{array}$ & $\begin{array}{c}\text { Post- } \\
\text { test }\end{array}$ \\
\hline Eksperimen & $\mathrm{O}_{1}$ & $\mathrm{X}_{1}$ & $\mathrm{O}_{2}$ \\
\hline Kontrol & $\mathrm{O}_{1}$ & $\mathrm{X}_{2}$ & $\mathrm{O}_{2}$ \\
\hline
\end{tabular}

Gambar 1 Alur Pelaksanaan Penelitian

Keterangan:

$0_{1}$ : tes awal (sebelum diberikan layanan bimbingan kelompok) pada kelompok eksperimen dan kelompok kontrol

$\mathrm{O}_{2}$ : tes akhir (setelah diberikan layanan bimbingan kelompok) pada kelompok eksperimen dan kelompok kontrol

$\mathrm{X}_{1}$ : menggunakan kartu angka

$\mathrm{X}_{2}$ : perlakuan konvensional/tanpa perlakuan

Berdasar pada rancangan kuasi eksperimen, dapat diuraikan dalam bagan berikut.
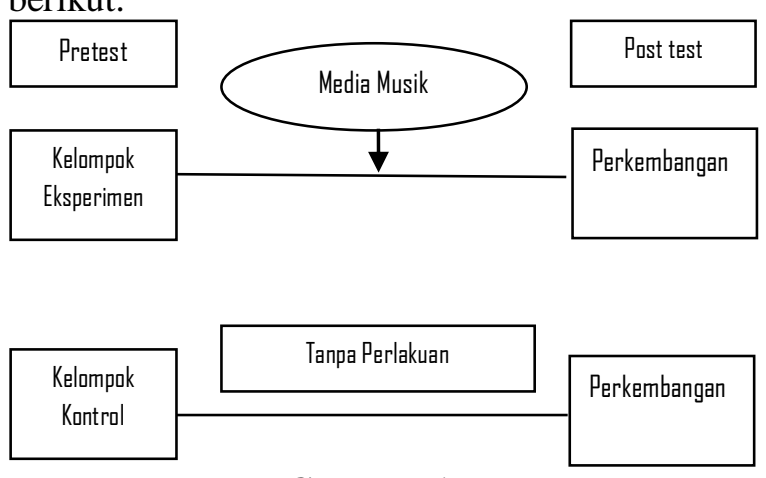

Gambar 1

Rancangan Perlakuan Kuasi Eksperimen
Subjek penelitian ini adalah anak Taman Kanak-Kanak Kelompok A1 yang berjumlah 30 orang, dan kelompok A2 yang berjumlah 30 orang. Objek dalam penelitian ini adalah kemampuan mengenal konsep angka 1-10.

Penelitian ini dilaksanakan dalam 8 tahapan, yang pertama pemberian pre test kepada kelompok kontrol dan eksperimen untuk mengetahui kemampuan siswa dalam mengenal angka. Setelah pemberian pretest, diberikan perlakuan yaitu berupa pengenalan konsep angka 1-10 dengan menggunakan media kartu angka, kemudian baru diberikan posttest.

Kemampuan yang diteliti dalam penelitian ini adalah adalah menyebutkan urutan angka 1-10, membuat urutan angka 110, dan menghubungkan dan memasangkan lambang angka dengan benda-benda 1-10.

Untuk mengumpulkan data penelitian, digunakan metode observasi. Observasi merupakan suatu cara dalam memperoleh data atau mengumpulkan data dengan jalan mengadakan pengamatan dan pencatatan secara sistematis tentang suatu objek tertentu (Agung, 2010). Kemudian, dilakukan analisa dengan menggunakan rumusan $\mathrm{Uji} \mathrm{T}$ serta dalam penghitungannya dibantu dengan menggunakan SPSS versi 20.

\section{HASIL DAN PEMBAHASAN}

Dari hasil penelitian yang telah dilakukan terhadap kelompok kontrol, setelah diberikan pre test dan kemudian kelompok ini melakukan pembelajaran konvensional sebanyak enam kali, lalu diberikan posttest, maka didapatkan hasil berikut:

Paired Samples Test

\begin{tabular}{|c|c|c|c|c|c|c|c|}
\hline \multicolumn{5}{|c|}{ Paired Differences } & \multirow[t]{3}{*}{$\mathrm{t}$} & \multirow[t]{3}{*}{$\mathrm{df}$} & \multirow{3}{*}{$\begin{array}{c}\text { Sig. } \\
(2- \\
\text { tailed) }\end{array}$} \\
\hline \multirow[t]{2}{*}{$\begin{array}{c}\mathrm{Me} \\
\text { an }\end{array}$} & \multirow[t]{2}{*}{$\begin{array}{l}\mathrm{St} \\
\mathrm{d} . \\
\mathrm{D} \\
\mathrm{ev} \\
\text { ia } \\
\text { ti } \\
\mathrm{o} \\
\mathrm{n}\end{array}$} & \multirow[t]{2}{*}{$\begin{array}{l}\mathrm{St} \\
\mathrm{d} . \\
\mathrm{Er} \\
\mathrm{ro} \\
\mathrm{r} \\
\mathrm{M} \\
\mathrm{ea} \\
\mathrm{n}\end{array}$} & \multicolumn{2}{|c|}{$\begin{array}{c}95 \% \\
\text { Confi } \\
\text { dence } \\
\text { Interv } \\
\text { al of } \\
\text { the } \\
\text { Differ } \\
\text { ence } \\
\end{array}$} & & & \\
\hline & & & $\begin{array}{c}\mathrm{L} \\
\mathrm{O} \\
\mathrm{W} \\
\mathrm{er}\end{array}$ & $\begin{array}{l}\mathrm{U} \\
\mathrm{pp} \\
\mathrm{er}\end{array}$ & & & \\
\hline
\end{tabular}




\begin{tabular}{|c|c|c|c|c|c|c|c|c|}
\hline $\begin{array}{ll}\text { P } & \text { Prete } \\
\text { a } & \text { st - } \\
\text { ir } & \text { Postt } \\
1 & \text { est }\end{array}$ & $\begin{array}{r}1,8 \\
33\end{array}$ & $\begin{array}{r}6 \\
0 \\
2 \\
9\end{array}$ & $\begin{array}{r}1, \\
10 \\
1\end{array}$ & $\begin{array}{r}- \\
, 4 \\
18\end{array}$ & $\begin{array}{r}4 \\
08 \\
5\end{array}$ & $\begin{array}{r}1, \\
66 \\
6\end{array}$ & 29 & ,107 \\
\hline
\end{tabular}

Dari hasil penghitungan di atas yang dilakukan terhadap kelompok kontrol, disimpulkan bahwa sig $(0,107)>0,05$ maka Ho diterima. Artinya, tidak ada perbedaan pada kelompok ini. Pada kelompok kontrol, pembelajaran mengenal angka 1-10 tidak menggunakan kartu angka. Siswa belajar dengan model pembelajaran yang biasa dilakukan sehari-hari.

Sedangkan pada kelompok eksperimen, dari hasil penghitungan yang telah dilakukan, dapat diartikan bahwa sig $(0,000)$ $<0,05$ yang berarti ada perbedaan dalam pengenalan angka dengan menggunakan kartu angka.

Pada kelompok eksperimen, pembelajaran mengenal angka dilakukan dengan menggunakan media kartu angka. Dalam hal ini, ada perbedaan sebelum dan sesudah perlakuan. Siswa lebih mudah untuk mengenal dan mengerti tentang konsep angka. Hasil penghitungan tampak dalam tabel dibawah ini:

Perbandingan antara kelompok kontrol dan kelompok eksperimen dilakukan untuk melihat pengaruh kartu angka dalam mengembangkan kemampuan mengenal angka pada anak kelompok A.

Dari hasil penghitungan yang telah dilakukan terhadap kelompok kontrol dan kelompok eksperimen, sig $(0,000)<0,05$ maka dapat dikatakan ada perbedaan antara kelompok kontrol dan kelompok eksperimen dalam pengenalan angka 1-10 dengan menggunakan kartu angka.

Proses pembelajaran yang menggunakan media lebih berjalan dengan optimal dibandingkan dengan metode pembelajaran yang klasikal. Media merupakan salah satu hal yang mendukung dalam pengenalan angka kepada anak khususnya anak usia dini.

Peran media dalam pembelajaran merupakan segala sesuatu yang dapat digunakan untuk menyalurkan pesan pengirim kepada penerima, sehingga dapat merangsang pikiran, perasaan, perhatian dan minat belajar siswa yang nantinya akan mengarah kepada terjadinya proses belajar. (https://witarafianti.wordpress.com/2016/04/21 /media-yang-digunakan-dalam-proses-belajarbimbingan-konseling-anak-di-sekolah/).

Pemanfaatan kartu angka dalam pembelajaran ini dapat membuat proses belajar menjadi menyenangkan. Anak menjadi tertarik dan tidak bosan terutama berkaitan dengan pengenalan angka. Selain itu, dengan menggunakan kartu angka, anak juga lebih mudah mengingat angka karena dalam media yang digunakan ini, ada pengulanganpengulangan yang semakin menguatkan pembelajaran dalam mengenal angka. Proses pembelajaran yang dilakukan seraya bermain membuat anak menjadi lebih tertarik dan tidak mudah bosan.

Bagi anak usia dini, bermain merupakan kegiatan yang dilakukan sepanjang hari dan dengan bermain anak dapat belajar tentang apa yang ingin mereka ketahui dan pada akhirnya mampu untuk mengenal semua peristiwa yang terjadi di sekitarnya tanpa merasa tertekan.

Paired Samples Test

\begin{tabular}{|c|c|c|c|c|c|c|c|c|}
\hline & \multicolumn{5}{|c|}{ Paired Differences } & \multirow[t]{3}{*}{$\mathrm{t}$} & \multirow[t]{3}{*}{ Df } & \multirow{3}{*}{$\begin{array}{l}\text { Sig. } \\
(2- \\
\text { taile } \\
\text { d) }\end{array}$} \\
\hline & \multirow[t]{2}{*}{$\begin{array}{c}\mathrm{M} \\
\text { ea } \\
\mathrm{n}\end{array}$} & \multirow[t]{2}{*}{$\begin{array}{c}\text { Std } \\
\cdot \\
\text { De } \\
\text { via } \\
\text { tio } \\
\text { n }\end{array}$} & \multirow[t]{2}{*}{$\begin{array}{l}\text { Std. } \\
\text { Err } \\
\text { or } \\
\text { Me } \\
\text { an }\end{array}$} & \multicolumn{2}{|c|}{$\begin{array}{c}95 \% \\
\text { Confiden } \\
\text { ce } \\
\text { Interval } \\
\text { of the } \\
\text { Differenc } \\
\mathrm{e} \\
\end{array}$} & & & \\
\hline & & & & $\begin{array}{c}\text { Lo } \\
\text { wer }\end{array}$ & $\begin{array}{c}\text { Upp } \\
\text { er }\end{array}$ & & & \\
\hline $\begin{array}{ll}\text { P } & \text { Pret } \\
\text { a } & \text { est - } \\
\text { ir } & \text { Post } \\
1 & \text { test }\end{array}$ & $\begin{array}{r}- \\
7 \\
83 \\
3\end{array}$ & $\begin{array}{r}3,7 \\
97\end{array}$ & $\begin{array}{r}69 \\
3\end{array}$ & $\begin{array}{r}9,2 \\
51\end{array}$ & $\begin{array}{r}- \\
6,41 \\
5\end{array}$ & $\begin{array}{r}- \\
11, \\
29 \\
9\end{array}$ & 29 &, 000 \\
\hline
\end{tabular}

Pada kelompok eksperimen dan kelompok kontrol, dapat terlihat jelas perbedaan bahwa siswa yang berada dalam kelompok eksperimen lebih cepat menguasai dan hafal tentang angka 1-10 dibandingkan dengan kelompok kontrol. Mengenal angka juga merupakan proses yang sangat penting untuk dikembangkan dikarenakan merupakan dasar kemampuan matematika pada anak. Kemampuan mengenal lambang bilangan yang baik sejak anak usia dini akan memudahkan bagi anak untuk memahami operasi bilangan pada tingkat pendidikan selanjutnya. Anak dikatakan mengenal lambang bilangan dengan baik apabila tidak hanya sekedar menghafal 
lambang bilangan, namun mereka juga mengenal bentuk makna dari bilangan tersebut dengan baik.

Pemberian perlakuan yang diberikan sebanyak 6 kali baik pada kelompok eksperimen, dari 30 siswa sebelum ada pemberian perlakuan dengan menggunakan kartu angka, sebanyak 23 siswa masih belum mengenal lambang bilangan dengan baik. Mereka hanya bisa menghafal secara berurutan. Saat lambang bilangan diacak, mereka belum mengenal bentuk dan makna lambang bilangan tersebut. Hal ini berarti, penggunaan media yang menarik juga sangat mendukung belajar siswa.

Pada kelompok kontrol, kurangnya kemampuan anak mengenal lambang bilangan 1 - 10 dikarenakan pembelajaran yang dilakukan hanya sebatas anak ditunjukkan lambang bilangan dan diminta untuk mencari gambar yang sesuai dengan lambang bilangan tersebut. Dari 28 siswa, hanya ada 6 siswa yang mengenal lambang bilangan dengan baik. Hal ini dikarenakan mereka sudah dikenalkan dengan lambang bilangan oleh orang tua sebelum masuk TK.

Dari perbandingan kedua kelompok tersebut, pembelajaran yang dilakukan dengan menggunakan kartu angka membuat anak lebih tertarik sehingga dapat meningkatkan perhatian dan keaktifan anak dalam bermain sambil belajar.

\section{KESIMPULAN}

Penelitian ini menunjukkan bahwa ada peningkatan dalam kemampuan mengenal bilangan dengan menggunakan program bimbingan media musik ini.

Sehubungan dengan hasil penelitian yang telah dilakukan, saran-saran yang perlu disampaikan dalam penelitian ini, yaitu kepada anak, disarankan untuk lebih bersemangat dan memiliki motivasi dalam meningkatkan kemampuan mengenal bilangan melalui media musik ini. Saran juga diberikan kepada guru, yaitu diharapkan dapat meningkatkan kreativitas dan kemampuan dalam melaksanakan kegiatan pembelajaran yang lebih inovatif dan kreatif serta disesuaikan dengan kebutuhan perkembangan anak.

\section{REFERENSI}

Asnawir. 2002. Media Pembelajaran. Jakarta. PT. Bina Aksara
Departemen Pendidikan Nasional Direktorat Jenderal Manajemen Pendidikan Dasar dan Menengah Direktorat Pembinaan Taman Kanak-Kanak dan Sekolah Dasar. Permainan Berhitung Permulaan. Jakarta. 2007

Fitriyanti. 2015. Meningkatkan Kemampuan Mengenal Angka 1-10 Dengan Media Gambar Asosiatif di Kelompok B TK Budi Rahayu. Program Studi PG-PAUD Jurusan Pendidikan Anak Usia Dini. Fakultas Ilmu Pendidikan. Universitas Negeri Yogyakarta. Skripsi.

Hasan. 2009. Pendidikan Anak Usia Dini. Yogyakarta. Diva Press.

Jarwati. 2012. Peningkatan Kemampuan Mengenal Konsep Angka Dengan Bermain Kartu Angka Bergambar pada Siswa Kelompok B TK Pertiwi Kayumas I Kecamatan Jatinom Klaten Tahun Ajaran 2012/2013. Fakultas Keguruan dan Ilmu Pendidikan. Universitas Muhammadiyah Surakarta. Skripsi.

Mayke Tedjasaputra. 2001. Bermain, Mainan dan Permainan. Jakarta : Grasindo

Pujiastutik dan Setyowati. 2010. Meningkatkan Kemampuan Mengenal Konsep Bilangan Menggunakan Media Kartu Batang Angka di KB Puspa Hati Kecamatan Pungging Kabupaten Mojokerto. Program Studi PG-PAUD, Fakultas Ilmu Pendidikan, Universitas Negeri Surabaya. Skripsi.

Sanaky. 2011. Media Pembelajaran. Yogyakarta. Kaukeba

Sugiyono. (2011). Metode Penelitian Kuantitatif, Kualitatif Dan $R \& D$. Bandung: Alfabeta

Tarjono. 2003. Pengenalan dan Pemahaman Terhadap Bilangan. Jakarta.

Tadkirotun. 2012. Pengembangan Kecerdasan Majemuk. Tangerang. Universitas Terbuka.

file:///C:/Users/user/Downloads/2527-4449-1SM.pdf).

http://jun212w.blogspot.co.id/2013/12/peneliti an-tindakan-kelas_17.html

https://witarafianti.wordpress.com/2016/04/21/ media-yang-digunakan-dalam-prosesbelajar-bimbingan-konseling-anak-disekolah/ 